\title{
Identification of potential embryokines in the bovine reproductive tract
}

\author{
P. Tríbulo, ${ }^{*} \dagger$ L. G. B. Siqueira, ${ }^{*} \dagger \ddagger$ L. J. Oliveira, $† \S$ T. Scheffler, ${ }^{*}$ and P. J. Hansen ${ }^{*} \dagger{ }^{1}$ \\ *Department of Animal Sciences, and \\ †D.H. Barron Reproductive and Perinatal Biology Research Program, University of Florida, Gainesville 32611 \\ †Embrapa Gado de Leite, Juiz de Fora, MG, Brazil 36038-330 \\ $\S$ Department of Infectious Disease and Pathology, College of Veterinary Medicine, University of Florida, Gainesville 32611-0910 \\ \#Genetics Institute, University of Florida, Gainesville 32611
}

\begin{abstract}
Knowledge of the molecules used by the maternal reproductive tract to regulate development of the preimplantation embryo is largely incomplete. The goal of the present experiment was to identify candidates for this function. The approach was to assess expression patterns in the endometrium and oviduct of 93 genes encoding for hormones, growth factors, chemokines, cytokines, and WNT-related molecules. Results show that all of the genes were expressed in the reproductive tract. Expression in oviduct was affected by day of the estrous cycle for 21 genes with 11 genes having highest expression at estrus (CCL21, CTGF, CXCL10, CXCL16, DKK3, FGF10, IL18, IL33, IL34, PGF, and SFRP2), 1 gene at d 3 (WNT4), 8 at d 5 (BMP \%, HGF, IL6, SFRP1, TGFB1, WIF1, WNT2, and WNT5A), and 1 at $\mathrm{d} 7(I K)$. For endometrium, expression of 34 genes was affected by day of the estrous cycle with 11 having highest expression at d 0 (BMP 7, CCL14, CCL21, CCL26, CTGF, CXCL12, IGF2, IL16, IL33, SFRP2, and WIF1), 2 at d 3 (HDGF, IL15), 14 at d 5 (CSF2, CX3CL1, CXCL3, FGF1, FGF2, GRO1, HGF, IGF1, IL1B, IL8, SFRP1,SFRP4, WNT5A, and WNT16), and 7 at d 7 (CXCL16, FGF13, HDGFRP2, TDGF1, VEGFB, WNT7A, and WNT11). Results are consistent with a set of genes regulated by estradiol early in the estrous cycle and another set regulated by progesterone later in the cycle. The cell-signaling genes identified here as being expressed in the oviduct and endometrium could serve to regulate early embryonic development in a stage-of-pregnancy-specific manner.
\end{abstract}

Key words: embryokine, histotroph, endometrium, oviduct, maternal-embryo crosstalk

Received August 15, 2017.

Accepted September 19, 2017.

${ }^{1}$ Corresponding author: pjhansen@ufl.edu

\section{INTRODUCTION}

The environment established by the mother for the preimplantation embryo plays a key role in ensuring that development proceeds in a manner that optimizes pregnancy success and postnatal development. Disruption of maternal physiology during the preimplantation period can compromise embryonic survival. Examples include the effect of establishing an abnormal ratio of estradiol to progesterone in mice (Yoshinaga and Adams, 1966) and humans (Simón et al., 1995) and exposure of female embryo transfer recipients to bisphenol A in mice (Xiao et al., 2011). Other conditions can enhance maternal capacity for supporting development, as shown in cattle for treatment with somatotropin (Moreira et al., 2002). The maternal environment during the preimplantation period can also alter the developmental program of the embryo in a manner that alters postnatal phenotype [see review by Hansen et al. (2016)]. For example, feeding a diet low in protein during the preimplantation period modified postnatal growth and accumulation of body fat in rodents (Fleming et al., 2015).

The importance of the maternal environment for embryonic development is illustrated by the consequences of embryo production in vitro. In cattle, embryos produced in vitro experience altered gene expression (Corcoran et al., 2006; McHughes et al., 2009; Gad et al., 2012), metabolism (Khurana and Niemann, 2000), lipid content (Crosier et al., 2000; Sudano et al., 2012), ultrastructure (Boni et al., 1999; Rizos et al., 2002), DNA methylation (Niemann et al., 2010), and competence to establish pregnancy (Lonergan et al., 2007; Pontes et al., 2009). Moreover, properties of the resultant offspring can be disrupted in cattle (Siqueira et al., 2017) and other species (Fernandez-Gonzalez et al., 2004; Farin et al., 2006; Ceelen et al., 2008). Transfer of embryos produced in vitro to the oviduct can mitigate at least some of these abnormalities (Enright et al., 2000; Lazzari et al., 2010; Gad et al., 2012), indicating the importance of maternal signals for optimal development. 
An important mechanism by which the maternal oviduct and endometrium direct embryonic development is through secretion of regulatory molecules called embryokines. Several growth factors can affect embryonic development in various species. Among the most studied embryokines are colony-stimulating factor 2 (CSF2; Sjoblom et al., 1999; Loureiro et al., 2009, 2011; Denicol et al., 2014), IGF1 (Lin et al., 2003; Jousan and Hansen, 2007; Bonilla et al., 2011), and leukemia inhibitor factor (LIF; Kauma and Matt, 1995; Mohamed et al., 2004; Neira et al., 2010).

In many cases, it is unknown whether molecules that affect embryonic development in vitro are present in the reproductive tract at times coincident with development of the preimplantation embryo. In addition, other regulatory molecules are likely produced by the reproductive tract that can act on the preimplantation embryo. Indeed, the embryo is poised to respond to a plethora of maternal regulatory molecules because of the wide range of growth factor and hormone receptor genes that it expresses (Graf et al., 2014; Zuo et al., 2016).

The objective of the present study was to identify potential embryokines during the first $7 \mathrm{~d}$ after ovulation in the cow. It is during this period that the bovine embryo develops from the zygote to the blastocyst stage, where it spends the first 4 to $5 \mathrm{~d}$ in the oviduct, and then moves into the uterine lumen (Betteridge and Fléchon, 1988). The approach was to collect oviductal and endometrial tissue and determine the relative amounts of expression of genes for 93 hormones, growth factors, cytokines, chemokines, and WNT-related molecules that could potentially function as embryokines.

\section{MATERIALS AND METHODS}

\section{Synchronization of the Estrous Cycle}

The reproductive status of nonlactating Holstein cows was assessed by transrectal ultrasonography and 20 cows with a detectable corpus luteum were subjected to a hormonal protocol to synchronize ovulation. On $\mathrm{d}-18$ (day of expected ovulation $=\mathrm{d} 0$ ), cows were injected i.m. with $25 \mathrm{mg}$ of $\mathrm{PGF}_{2 \alpha}$ (Lutalyse, Zoetis, Florham Park, NJ) followed by $100 \mu \mathrm{g}$ of gonadorelin (GnRH; Cystorelin, Merial Inc., Duluth, GA) on d -16. A second, identical injection of $\mathrm{GnRH}$ was given on $\mathrm{d}$ -9 and a progesterone-containing controlled internal drug release device (CIDR, Zoetis) was inserted intravaginally. At $\mathrm{d}-4$, each cow was administered $25 \mathrm{mg}$ of $\mathrm{PGF}_{2 \alpha}$ i.m. and the intravaginal device was removed. Another $25 \mathrm{mg}$ of $\mathrm{PGF}_{2 \alpha}$ was injected at $\mathrm{d}-3$ and 100 $\mu \mathrm{g}$ of $\mathrm{GnRH}$ was injected i.m. at d -2 (i.e., $24 \mathrm{~h}$ after
$\left.\mathrm{PGF}_{2 \alpha}\right)$. Transrectal ultrasonography of ovaries was performed on $\mathrm{d}-4,-1$, and 0 to confirm ovulation. A total of 15 cows were successfully synchronized and slaughtered at either d $0(\mathrm{n}=4), 3(\mathrm{n}=4), 5(\mathrm{n}=$ $3)$, or $7(\mathrm{n}=4)$ relative to the day of ovulation. Cows within group were split into 2 groups that were slaughtered on 2 different days. Slaughter was by captive-bolt stunning and exsanguination at a commercial abattoir.

\section{Collection of Oviductal and Endometrial Tissues and Flushings}

Reproductive tracts were obtained immediately after slaughter and placed on ice. Processing of all organs was completed within a maximum of $4 \mathrm{~h}$ from slaughter of the first cow. Side of the reproductive tract was identified as being ipsilateral or contralateral to the side of ovulation. Ovulation of cows slaughtered at d 0 was confirmed by absence of a preovulatory follicle in 3 of 4 cows. For the remaining cow, ovaries were lost during processing and ovulation could not be confirmed.

After dissecting the oviduct free from the mesosalpinx, the caudal third of the oviduct, corresponding to the isthmus, was used to cut transversal 1-mm sections while the oviduct was gently stretched. Samples were snap frozen in liquid $\mathrm{N}_{2}$ for evaluation of gene expression. Samples were stored in liquid $\mathrm{N}_{2}$ until transport to the laboratory and storage at $-80^{\circ} \mathrm{C}$.

Uterine flushings and samples of endometrium were collected separately from both uterine horns. The mesometrium was removed and each uterine horn was clamped near the uterine body. The end near the uterotubal junction was opened with a $0.5-\mathrm{cm}$ incision and $30 \mathrm{~mL}$ of Dulbeccos's PBS at room temperature were flushed into the uterine horn from the opposite end using an 18-gauge needle. The fluid was propelled by massage along the uterine horn through the incision. Recovered fluid was kept on ice; after centrifugation at $3,000 \times g$ for $15 \mathrm{~min}$ at $4^{\circ} \mathrm{C}$, the supernatant fraction was obtained and stored at $-20^{\circ} \mathrm{C}$.

After flushing, each uterine horn was opened with a longitudinal incision along the major curvature. Intercaruncular regions of endometrial tissue were harvested from the middle section of uterine horns using a scalpel and tweezers. Three samples per cow were snap frozen, and 2 other samples were frozen in optimal cutting temperature medium (O.C.T., Sakura Finetek USA Inc., Torrance, CA) on dry ice covered with 2 methylbutyrate for immunofluorescence analyses. All samples were stored in liquid $\mathrm{N}_{2}$ until transport to the laboratory where they were stored at $-80^{\circ} \mathrm{C}$.

Note that limited resources prevented collection of caruncular endometrium. Intercaruncular endometrium 
was chosen for analysis because most of the surface of the endometrium is intercaruncular and the tissue is easy to identify and sample.

\section{RNA Extraction and Gene Expression}

Gene expression analysis was performed for endometrial and oviductal samples from all animals $(\mathrm{n}=4$ at $\mathrm{d}$ $0, \mathrm{n}=4$ at $\mathrm{d} 3, \mathrm{n}=3$ at $\mathrm{d} 5$, and $\mathrm{n}=4$ at $\mathrm{d} 7$ ). A total of 17 samples were subjected to analysis (from each of the 15 cows and with 2 cows being analyzed twice to assess technical variation). One snap-frozen sample of endometrium and one of oviduct of each animal were thawed and homogenized in lysis buffer from Qiagen RNeasy Mini kit (Qiagen, Valencia, CA) using a tissue homogenizer (Tissue Master 125, OMNI International, Kennesaw, GA) for $10 \mathrm{~s}$ at speed 4 . Homogenized tissue in lysis buffer was transferred to the silica columns of the Qiagen RNeasy Mini kit and RNA was extracted by following the manufacturer's instructions (https:// www.qiagen.com/us/shop/sample-technologies/rna/ total-rna/rneasy-mini-kit/\#resources) including DNase treatment.

Abundance of specific mRNA molecules for 93 genes potentially involved in control of embryonic development was determined using the NanoString nCounter analysis system (NanoString Technologies, Seattle, WA; Geiss et al., 2008). This analytical procedure consists of gene-specific 100-mer probe pairs (i.e., one probe that captures the target gene and one probe that serves as reporter) that are hybridized to the sample in solution. The reporter probe carries a fluorescent signal, and only probe pairs that hybridize to transcripts in the sample are immobilized and captured for data collection. Probes were designed to quantify mRNA for 28 growth factors, 12 chemokines, 22 cytokines, 3 hormones, 19 WNT ligands, and 9 WNT regulatory molecules. Target genes were selected on the basis that they code for secretory molecules shown to affect preimplantation embryonic development, or that they participate in signaling pathways active during the preimplantation period such as WNT signaling. In addition to the 93 regulatory molecule genes, expression of an aminopeptidase (ANPEP) was also measured as an internal control because it has been shown to be highly expressed in bovine endometrium at $\mathrm{d} 5$ and 7 after ovulation (Forde et al., 2009). Expression of 6 housekeeping genes (ACTB, RPL19, ERK1, GAPDH, SLC30A6, and SUZ12) was also assessed.

The 100-probe set was designed and synthesized by NanoString Technologies by identifying an optimal sequence within the target transcript that met the criteria of uniqueness in the genome and mutual independence from the other probes in the set (Supplemental File 1; https://doi.org/10.3168/jds.2017-13221). In addition to the customized arrays of probes, internal controls were included in the hybridization reaction.

The level of expression of mRNA was assessed using the NanoString nCounter gene expression system as described by Geiss et al. (2008). The samples were analyzed in 6 multiplexed hybridization reactions. Purified reactions were subjected to the digital analyzer to automatically acquire images and collect data by counting the number of times the reporter probe for each gene was detected. Technical variation was assessed for both oviduct and endometrium by analyzing samples from 2 cows in duplicate. The coefficient of variation among technical replicates averaged $4.3 \%$.

Data were first normalized to external RNA spikein controls (to account for hybridization efficiency) and then normalized to housekeeping genes $(A C T B$, ERK1, GAPDH, RPL19, SLC30A6, and SUZ12) using 2 normalization factors (i.e., one to adjust for spike-in controls and one for housekeeping genes). Each normalization factor was calculated for each sample by dividing average geometric mean of spike-in controls or housekeeping genes for all samples by the geometric mean for an individual sample.

Genes were considered expressed if the number of reads was greater than 2 standard deviations above the mean of negative controls (i.e., 10.4). For cases in which transcript was detectable for some samples but not others, the value used for statistical analysis for nondetectable samples was the minimum detection level (10.4).

Data were analyzed by least-squares ANOVA using the GLM procedure of SAS for Windows, version 9.4 (SAS Institute Inc., Cary, NC). The statistical model for expression in endometrium included the fixed effects of day, side, the day by side interaction, and the random effect of cow nested within day. Orthogonal contrasts were performed to identify the pattern of variation over days, including linear, quadratic, and cubic effects of day. Two statistical models were used for ANOVA of gene expression in oviduct. Gene expression data for tissue ipsilateral to the side of ovulation were analyzed with day as a fixed effect and the random effect of cow nested within day. Day effects were separated into individual degree-of-freedom comparisons using the same contrasts described for endometrial tissue. In a separate analysis, side was included in the statistical model as a fixed effect along with day and day by side interaction. In this case, only changes between $\mathrm{d} 0$ and 3 of the estrous cycle were evaluated because this is the period that coincides with embryonic development in the oviduct. Data are presented as least squares means \pm standard error of the mean. 


\section{Immunofluorescence}

Frozen tissue was processed on a Microm HM550 cryostatic microtome (ThermoFisher Scientific Inc., Waltham, MA) to obtain $4-\mu \mathrm{m}$ sections that were mounted on Superfrost plus slides (Fisher Scientific, Suwanee, GA) and kept at $-80^{\circ} \mathrm{C}$. Slides were fixed in ice-cold acetone for $10 \mathrm{~min}$ and allowed to dry for $1 \mathrm{~h}$ at room temperature. Rehydration was performed using Tris-buffered saline (TBS; $20 \mathrm{~m} M$ Tris-HCl, $\mathrm{pH}$ 7.5 containing $136.9 \mathrm{mM} \mathrm{NaCl}$ ) for $20 \mathrm{~min}$, followed by $1 \mathrm{~h}$ blocking with the same buffer containing either $10 \%$ (vol/vol) goat serum (Millipore, Billerica, MA) for WNT5A, WNT7A, and CSF2 or 10\% (vol/vol) horse serum (Atlanta Biologicals, Flowery Branch, GA) for dickkopf-related protein 1 (DKK1). One tissue block and 3 to 6 tissue sections were processed for each cow. Primary antibodies included rabbit polyclonal antibodies against human WNT5A and human WNT7A (Abcam, Cambridge, MA; 98.4 and $98.6 \%$ predicted AA sequence identity with bovine WNT5A and WNT7A, respectively), a mouse IgG1 monoclonal antibody against bovine CSF2 (GM-CSF 17.2 IgG1, Washington State University Monoclonal Antibody Center, Pullman, WA); and goat polyclonal anti-human DKK1 antibody (R\&D Systems Minneapolis, MN; 90.5\% predicted AA sequence identity with bovine DKK1).

All antibodies were diluted with TBS containing 1\% (vol/vol) goat serum, except for anti-human DKK1, which was diluted in TBS containing $1 \%$ ( $\mathrm{vol} / \mathrm{vol}$ ) horse serum. Concentrations were 5, 10, 10, and 0.2 $\mu \mathrm{g} / \mathrm{mL}$ for anti-WNT5A, WNT7A, CSF2, and DKK1, respectively. As a negative control, primary antibody was substituted with IgG of the species corresponding to the primary antibody. Incubation with primary antibodies proceeded overnight at $4^{\circ} \mathrm{C}$. Sections were then washed 3 times for 5 min using TBS containing 1\% (vol/ vol) goat serum, except for anti-human DKK1, which was washed with TBS containing $1 \%$ (vol/vol) horse serum. Secondary antibodies were diluted to a concentration of $6.66 \mu \mathrm{g} / \mathrm{mL}$ and incubated with tissue at room temperature for $1 \mathrm{~h}$. A goat anti-rabbit antibody conjugated to Alexa 555 was used for WNT5A, a goat anti-rabbit antibody conjugated to Alexa 488 was used for WNT7A, a goat anti-mouse antibody conjugated to Alexa 488 was used for CSF2, and a rabbit anti-goat antibody conjugated to Alexa 488 was used for DKK1. All secondary antibodies were from Life Technologies (Carlsbad, CA). Following labeling with second antibody and washing of sections with TBS, sections were incubated with $1 \mu \mathrm{g} / \mathrm{mL}$ of Hoechst 33342 for $10 \mathrm{~min}$ to label nuclei.

Slides were mounted using ProLong antifade reagent (Life Technologies), covered with a coverslip, and observed using a Zeiss Axioplan 2 epifluorescence microscope (Zeiss, Göttingen, Germany) and Zeiss filter sets 02 (4,6-diamidino-2-phenylindole), 03 (fluorescein isothiocyanate filter), and 04 (rhodamine). Digital images were acquired using AxioVision software (Zeiss) and a high-resolution black and white Zeiss AxioCam MRm digital camera.

\section{Western Blotting for CSF2}

All reagents were purchased from Fisher Scientific unless otherwise stated. Uterine flushings were thawed and $1 \mathrm{~mL}$ aliquots were precipitated with ice-cold acetone (1:4 dilution, vol:vol) for $60 \mathrm{~min}$ at $-20^{\circ} \mathrm{C}$. After centrifugation at $13,000 \mathrm{x}$ g for $10 \mathrm{~min}$, pellets were allowed to dry and then reconstituted with double distilled water. Samples were mixed with Laemmli buffer, heated for $5 \mathrm{~min}$ at $95^{\circ} \mathrm{C}$, and stored at $-80^{\circ} \mathrm{C}$ until analysis. Equal volumes were loaded into precast polyacrylamide gels (Mini-PROTEAN TGX 4-15\% polyacrylamide; Bio-Rad, Hercules, CA) and separated by SDS-PAGE at $110 \mathrm{~V}$ for $60 \mathrm{~min}$. Proteins were then transferred to a nitrocellulose membrane (Hybond ECL, GE Healthcare Life Sciences, Pittsburgh, PA) in a wet system using Tris-glycine transfer buffer $[0.06 \%$ (wt/vol) Tris base, $2.88 \%$ (wt/vol) glycine, $0.01 \%$ (wt/vol) SDS, $20 \%$ (vol/vol) methanol]. Protein transfer proceeded for 60 min at $65 \mathrm{~V}$ at $4^{\circ} \mathrm{C}$. After $1 \mathrm{~h}$ incubation with blocking buffer (StartingBlock, Thermo Scientific), blots were probed with $1 \mu \mathrm{g} / \mathrm{mL}$ of mouse IgG1 monoclonal antibody against bovine CSF2 (GM-CSF 17.2 IgG1, VMRD, Pullman, WA) diluted in blocking buffer containing $0.2 \%$ (vol/vol) Tween 20 and rocked overnight at $4^{\circ} \mathrm{C}$. As a negative control, other blots were probed with an equivalent concentration of mouse IgG1. After washing, membranes were incubated with $0.1 \mu \mathrm{g} / \mathrm{mL}$ goat anti-mouse IRDye $800 \mathrm{CW}$ conjugated anti-IgG antibody (LI-COR Biosciences, Lincoln, NE) for $1 \mathrm{~h}$ in the dark at $4^{\circ} \mathrm{C}$. Bands were visualized using Odyssey Infrared Imaging System (LI-COR Biosciences).

\section{RESULTS}

\section{Expression of Putative Embryokines Expressed in Oviduct}

Levels of expression of the 93 evaluated genes at each day of the estrous cycle are shown in Supplemental File 2 (https://doi.org/10.3168/jds.2017-13221) and the 50-highest expressed on each day are presented in Figure 1. Overall, wide variation was present in the magnitude of expression between genes. Average reads varied from 13,625 to 16 for the 50 most expressed genes. Of the 93 genes evaluated, all were expressed 
in the oviduct ipsilateral to the side of ovulation on $\mathrm{d}$ 0 and 3 of the estrous cycle. By d 5, however, only 71 genes were expressed. Those genes whose transcripts were not detectable were $A M H, B M P 15, C C L 4, D K K 4$, IFNB1, IL2, IL3, IL4, IL5, IL13, IL17A, IL21, SFRP5, TSHB, WNT1, WNT3, WNT3A, WNTrB, WNT8A, $W N T 8 B, W N T 9 B$, and $W N T 10 B$. Transcripts for these genes were also nondetectable at $\mathrm{d}$ 7. Moreover, 10 other genes were not expressed at d 7 (FGF11, FGF1, GDF9, IL10, IL1B, INHBA, PGF, WNT7A, WNT10A, and $W N T 11)$. The 10 most highly expressed genes in descending magnitude were CXCL12, CTGF, IGF2, SFRP2, WNT5A, IK, CXCL10, CXCL3, HDGFRP2, and HDGF at d 0; CXCL12, CTGF, IGF2, IK, IGF1, HDGF, WNT5A, CXCL3, CXCL10, and CCL14 at d 3; CTGF, GRO1, CXCL3, WNT5A, SFRP1, IL8, DKK3, $C X C L 12, I K$, and HDGF at d 5; and IK, CTGF, HDGF, CXCL12, HDGFRP2, CXCL3, GRO1, VEGFA, IGF2, and $V E G F B$ at $\mathrm{d} 7$ after ovulation. Of these, $C T G F$, $C X C L 3$, and $I K$ were among the 10 most abundant transcripts at each day.

A total of 21 genes were significantly affected by day of the estrous cycle (Table 1). Of these genes, 11 genes were most highly expressed at estrus (CCL21, CTGF, CXCL10, CXCL16, DKK3, FGF10, IL18, IL33, IL34, PGF, and SFRP2), 1 at d 3 (WNT4), 8 at d 5 (BMP $7, H G F, I L 6$, SFRP1, TGFB1, WIF1, WNT2, and $W N T 5 A)$, and 1 at $\mathrm{d} 7(I K)$.

Further analysis was conducted to determine if gene expression was affected by side of the oviduct relative to ovulation during the first $3 \mathrm{~d}$ of the estrous cycle when the embryo is resident within the oviduct. There was an effect of side of the oviduct for only 5 genes (DKK2, IL10, IL13, TGFB3, and WNT4). In each case, expression was higher for the oviduct ipsilateral to the side of ovulation than for the oviduct contralateral to the side of ovulation (Table 2). For 9 genes $(B M P 4$, CXCL12, CXCL16, FGF10, GRO1, HDGFRP2, IL34, $S F R P 2$, and $V E G F B$ ), the effect of side of ovulation depended on the day of the estrous cycle (Table 3 ). All of these genes were more abundant in the oviduct ipsilateral to the side of ovulation at $\mathrm{d} 0$, whereas side had little effect at d 3. Expression of BMP4, CXCL12, GRO1, HDGFRP2, SFRP2, and VEGFB was higher for the ipsilateral side at $\mathrm{d} 0$ but lower for the ipsilateral side at $d 3$.

\section{Expression of Putative Embryokines Expressed in Endometrium}

Data for all 93 evaluated genes are summarized in Supplemental File 3 (https://doi.org/10.3168/jds.2017 -13221) and the transcript abundance for the top 50 expressed genes at each day of the estrous cycle are displayed in Figure 2. Overall, there was wide variation in the magnitude of gene expression. For example, average reads varied from 26,609 to 21 for the top 50 most expressed genes across days.

All genes were expressed at d 0,3 , and 7 of the estrous cycle, but only 69 of the 93 genes were expressed on $\mathrm{d} 5$. Genes whose transcripts were not detected at d 5 were $A M H, B M P 15, C C L 21, C C L 26, D K K 4, F G F 14$, GDF9, IL2, IL3, IL4, IL5, IL10, IL13, IL21, SFRP5, TSHB, WNT1, WNT2B, WNT3, WNT7B, WNT8A, WNT8B, WNT9B, and WNT10B.

The 10 most highly expressed genes in descending magnitude were CTGF, CXCL12, WNT5A, WNT6, IGF2, CXCL3, WIF1, HDGF, IK, and VEGFA at d 0; WNT5A, CTGF, CXCL10, HDGF, CXCL3, IK, IGF2, CXCL12, VEGFA, and SFRP1 at d 3; WNT5A, TDGF1, CXCL3, CTGF, SFRP1, GRO1, IK, HDGF, IGF1, and VEGFA at d 5; and TDGF, WNT5A, $C T G F, V E G F B, I K, H D G F, S F R P 1, V E G F A, H D G-$ $F R P 2$, and $W N T 7 A$ at d 7 after ovulation. A total of 5 genes ( $C T G F, H D G F, I K, V E G F A$, and WNT5A) were among the 10 most highly expressed genes at each day of the estrous cycle.

Day of the estrous cycle affected expression of 34 genes (Table 4). Of these, 11 were most highly expressed at d 0 (BMP7, CCL14, CCL21, CCL26, CTGF, CXCL12, IGF2, IL16, IL33, SFRP2, and WIF1), 2 at d 3 (HDGF, IL15), 14 at d 5 (CSF2, CX3CL1, CXCL3, FGF1, FGF2, GRO1, HGF, IGF1, IL1B, IL8, SFRP1, SFRP 4, WNT5A, and WNT16), and 7 at d 7 (CXCL16, FGF13, HDGFRP2, TDGF1, VEGFB, WNT7A, and $W N T 11)$. Only one gene (IK) was differentially expressed between uterine horns, being higher for endometrium ipsilateral to the side of ovulation than for endometrium contralateral to the side of ovulation (900 \pm 42 vs. $788 \pm 43)$. There were also significant interactions between day and side for 6 genes (Table 5).

\section{Immunolocalization of Selected Embryokines Within Endometrium}

Protein localization in the endometrium was evaluated for 2 known embryokines (CSF2 and DKK1) and 2 WNT signaling molecules that were highly expressed in endometrium (WNT5A and WNT7A). Labeling for immunofluorescence was conducted using tissue from the day of the estrous cycle at which gene expression was highest (i.e., $\mathrm{d} 5$ for CSF2 and WNT5A and $\mathrm{d} 7$ for DKK1 and WNT7A).

The CSF2 was localized to the luminal epithelium, glandular epithelium, and stroma (Figure 3A). The same was true for WNT5A (Figure 3C) except labeling in the luminal epithelium was much more intense than labeling in other cell types. The DKK1 was lo- 


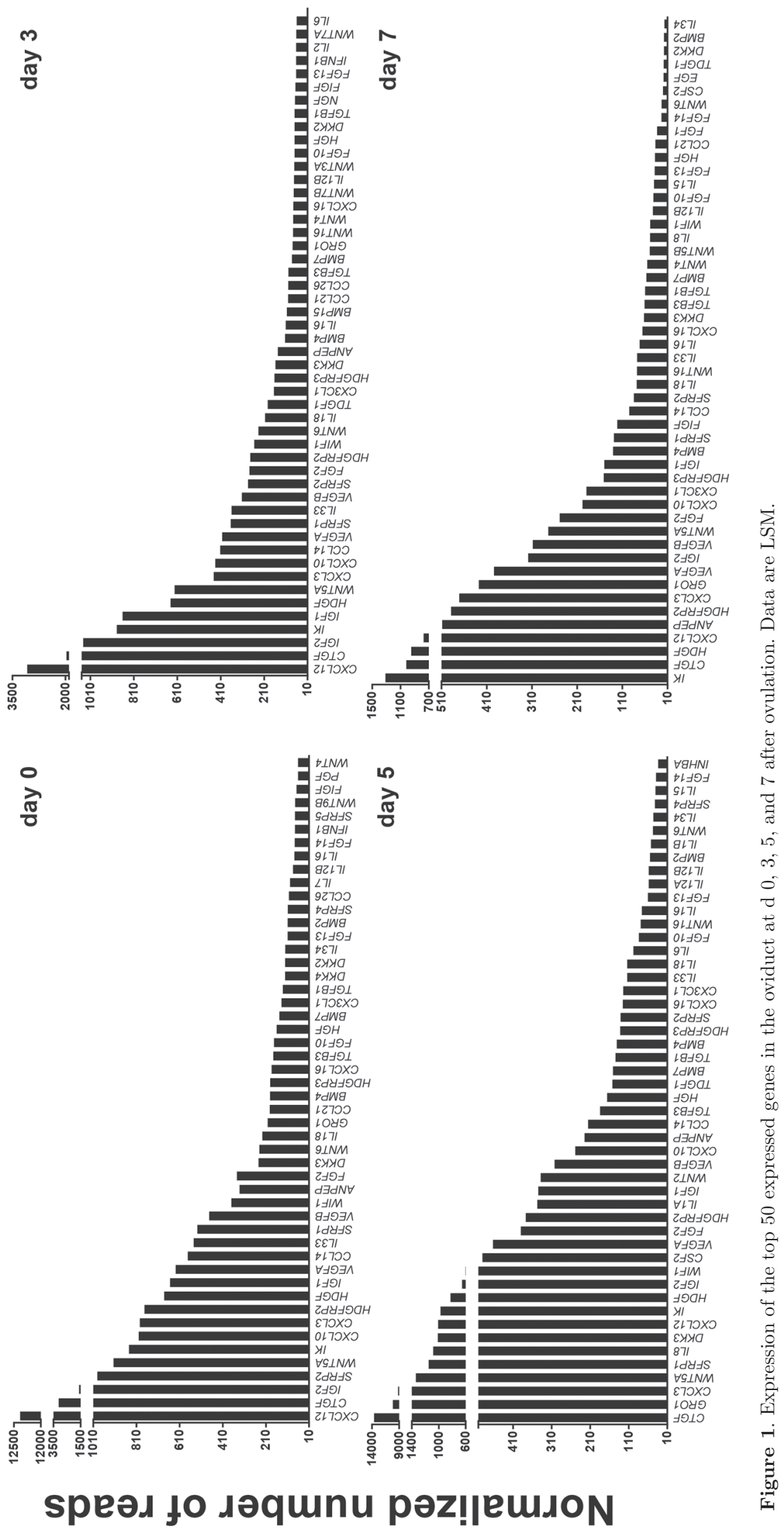


Table 1. Genes whose expression in the oviduct ipsilateral to the side of ovulation was affected by day of the estrous cycle within the first $7 \mathrm{~d}$ after ovulation

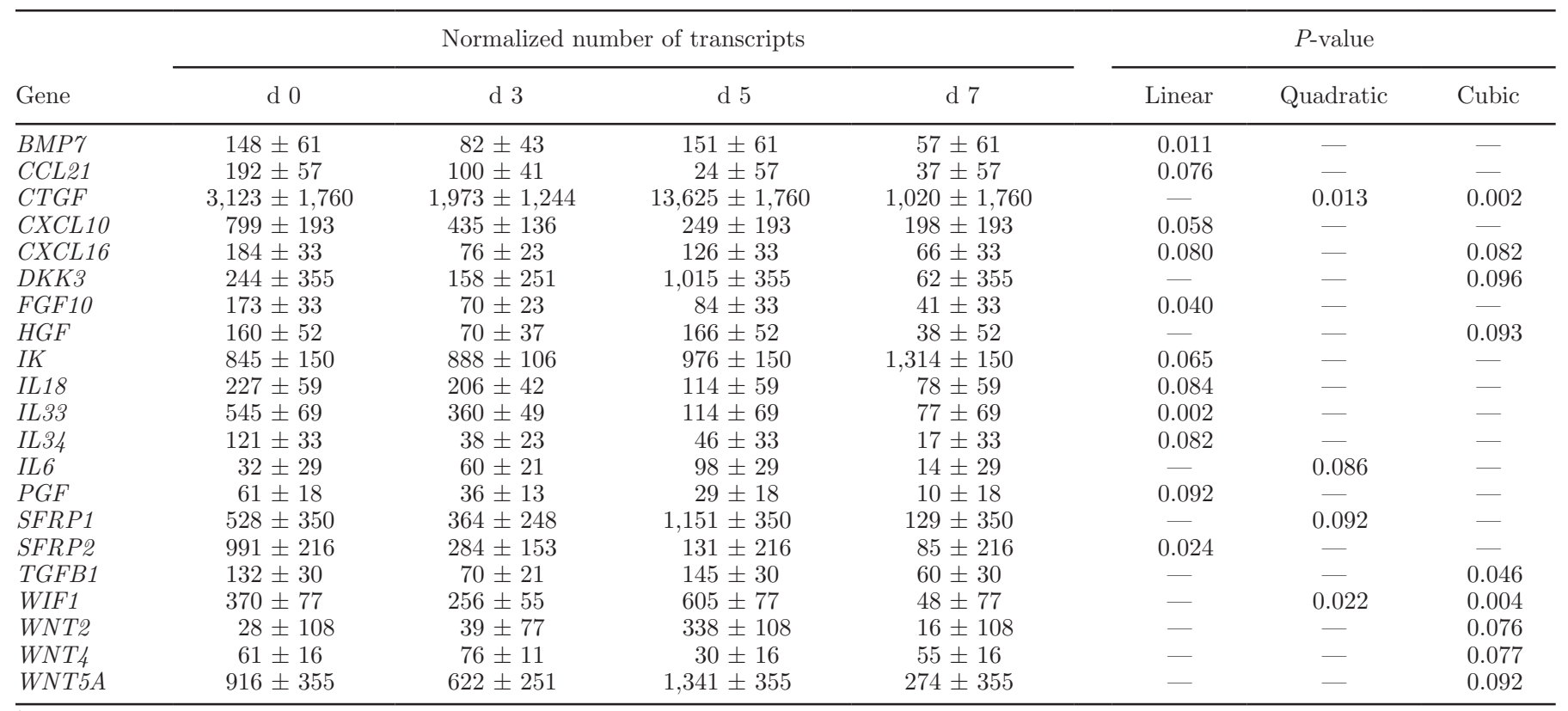

${ }^{1}$ Data are LSM \pm SEM. - indicates $P>0.10$.

calized primarily to endometrial stromal cells. It was not detectable in glandular epithelium but there was some labeling of luminal epithelial cells (Figure 3B). Immunoreactive WNT7A was localized to the apical surface of luminal and glandular epithelial cells and was present in stromal cells (Figure 3D).

\section{Accumulation of CSF2 in Uterine Flushings}

Immunoreactive CSF2 was detected in uterine flushings at $\mathrm{d} 3,5$, and 7 of the estrous cycle and, faintly, at d 0 (Figure 4). In each sample where immunoreactive CSF2 was present (2 of 4 samples at d 0,4 of 4 samples at d 3,3 of 3 samples at $d 5$, and 3 of 4 samples at $d$ 7 ), the most prominent immunoreactive protein was of molecular weight $=24,600$. This band was of higher

Table 2. Genes whose expression in the oviduct was differentially expressed between sides ipsilateral and contralateral to the side of ovulation within the first $3 \mathrm{~d}$ after ovulation ${ }^{1}$

\begin{tabular}{lrcc}
\hline & \multicolumn{3}{c}{$\begin{array}{c}\text { Normalized number } \\
\text { of transcripts }\end{array}$} \\
\cline { 2 - 3 } Gene & Ipsilateral & Contralateral & \\
\hline DKK2 & $96 \pm 24$ & $28 \pm 19$ & 0.052 \\
IL10 & $46 \pm 12$ & $17 \pm 10$ & 0.093 \\
IL13 & $46 \pm 12$ & $17 \pm 10$ & 0.082 \\
TGFB3 & $137 \pm 22$ & $61 \pm 18$ & 0.025 \\
WNT4 & $69 \pm 08$ & $41 \pm 07$ & 0.024 \\
\hline
\end{tabular}

${ }^{1}$ Data are LSM \pm SEM. molecular weight than either of the 2 immunoreactive bands identified in a preparation of recombinant CSF2 produced in yeast $(22,700$ and 19,600). Additional lower and higher molecular weight bands were identified in some samples, particularly at $\mathrm{d} 7$.

\section{DISCUSSION}

These results reveal that a large number of genes encoding for cell signaling proteins are expressed by the oviduct and endometrium of the reproductive tract of the cow during the first $7 \mathrm{~d}$ after ovulation. It is during this time when the bovine embryo develops to the blastocyst stage, first in the oviduct and, after d 4 to 5 , in the uterus (Betteridge and Fléchon, 1988). Many of the proteins encoded by these genes are likely to play important roles in development of the preimplantation embryo. Indeed, several proteins whose genes were expressed by the oviduct and endometrium in this study have been shown to modify embryonic development in the cow. These include activin A (Trigal et al., 2011; Kannampuzha-Francis et al., 2016), bone morphogenetic protein 4 (BMP4; La Rosa et al., 2011), CSF2 (Loureiro et al., 2009; Denicol et al., 2014), connective tissue growth factor (CTGF; Kannampuzha-Francis et al., 2016), DKK1 (Denicol et al., 2014), epidermal growth factor (EGF; Sakagami et al., 2012), fibroblast growth factor 2 (FGF2; Fields et al., 2011), hepatomaderived growth factor (HDGF; Gómez et al., 2014), IGF1 (Jousan and Hansen, 2007; Bonilla et al., 2011), 


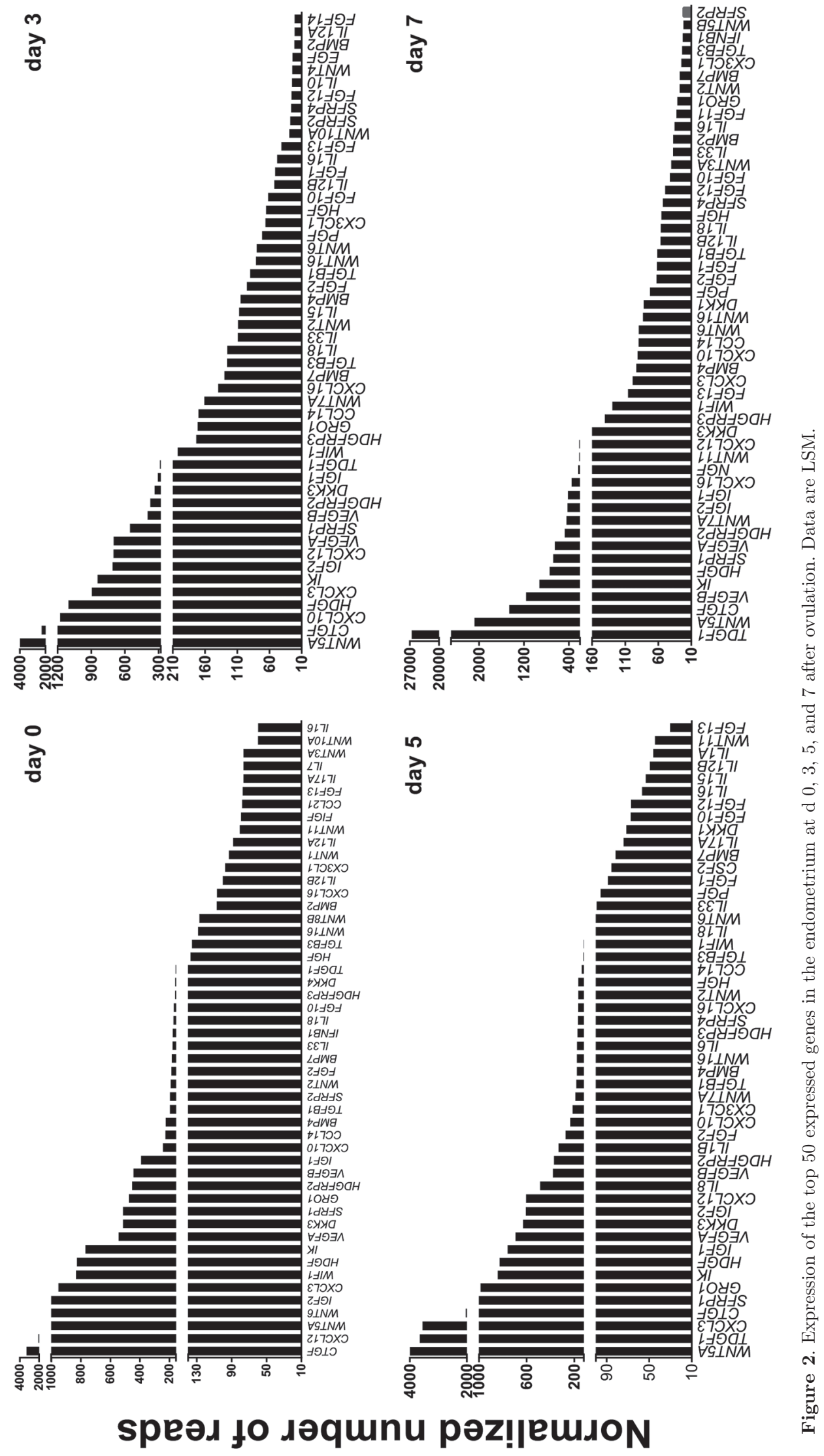


Table 3. Genes whose expression was affected by the interaction between location of the oviduct relative to the side of ovulation and day of the estrous cycle during the first $3 \mathrm{~d}$ after ovulation

Normalized number of transcripts

\begin{tabular}{|c|c|c|c|c|c|}
\hline \multirow[b]{2}{*}{ Gene } & \multicolumn{2}{|c|}{ d 0} & \multicolumn{2}{|c|}{ d 3} & \multirow[b]{2}{*}{$P$-value } \\
\hline & Ipsilateral & Contralateral & Ipsilateral & Contralateral & \\
\hline$C X C L 12$ & $12,385 \pm 3,463$ & $1,988 \pm 2,449$ & $3,085 \pm 2,449$ & $4,124 \pm 2,449$ & 0.063 \\
\hline CXCL16 & $184 \pm 22$ & $74 \pm 15$ & $76 \pm 15$ & $75 \pm 15$ & 0.010 \\
\hline$F G F 10$ & $173 \pm 31$ & $56 \pm 22$ & $70 \pm 22$ & $73 \pm 22$ & 0.037 \\
\hline GRO1 & $202 \pm 61$ & $74 \pm 43$ & $79 \pm 43$ & $254 \pm 43$ & 0.010 \\
\hline SFRP2 & $991 \pm 257$ & $280 \pm 181$ & $284 \pm 181$ & $469 \pm 181$ & 0.052 \\
\hline$V E G F B$ & $473 \pm 60$ & $253 \pm 42$ & $313 \pm 42$ & $390 \pm 42$ & 0.010 \\
\hline
\end{tabular}

${ }^{1}$ Data are LSM \pm SEM for effect of day by side interaction.

interleukin 1 \% (IL1ß) (Paula-Lopes et al., 1998), LIF (Mohamed et al., 2004; Neira et al., 2010; Mo et al., 2014), transforming growth factor beta (TGF $\beta$; Neira et al., 2010), and WNT7A (Tribulo et al., 2017). Other proteins encoded by genes expressed in the oviduct and endometrium have been implicated in regulation of preimplantation embryonic development in other species include nerve growth factor (NGF; Menino et

Table 4. Genes whose expression in the endometrium was affected by day of the estrous cycle within the first $7 \mathrm{~d}$ after ovulation ${ }^{1}$

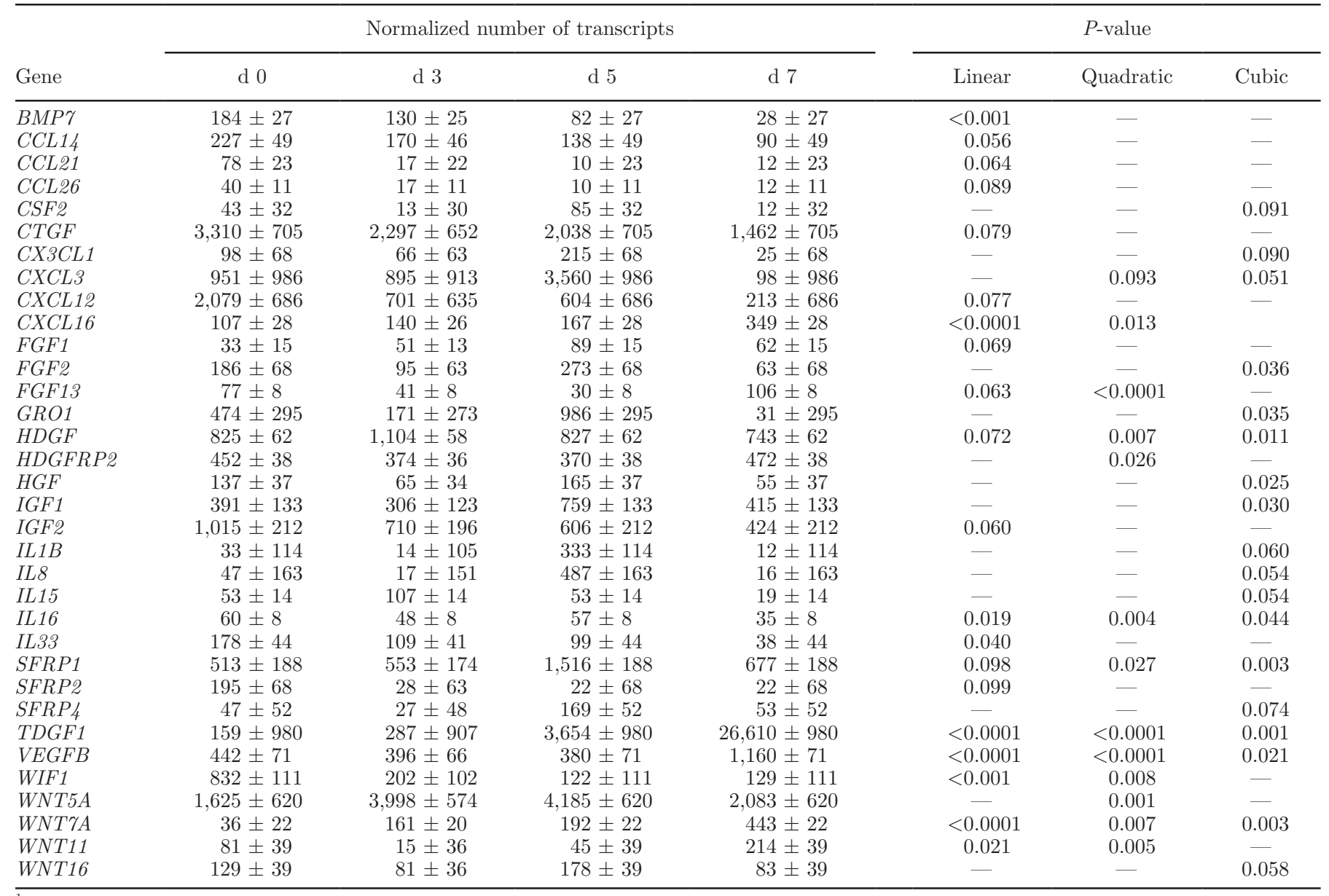

${ }^{1}$ Data are LSM \pm SEM. - indicates $P>0.10$. 


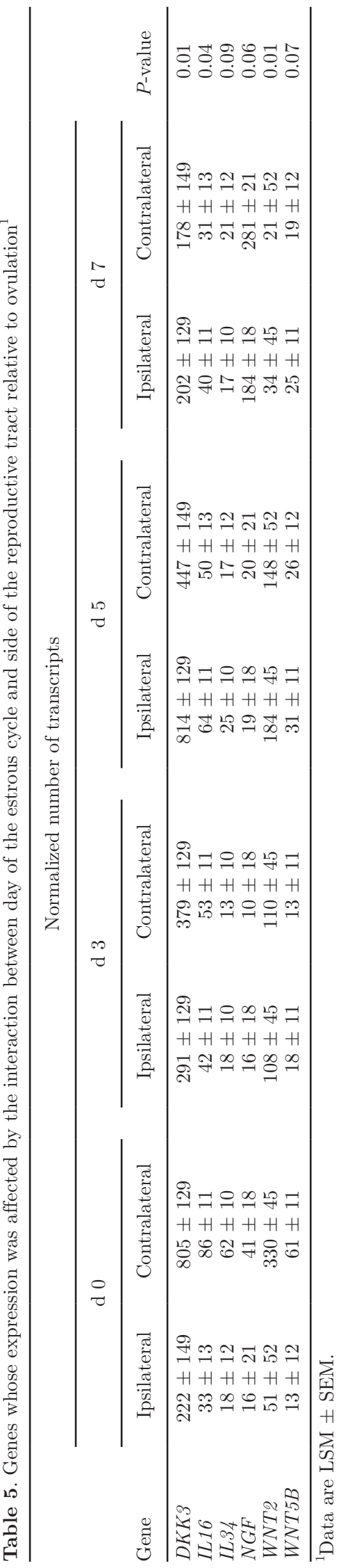

al., 1989), transforming growth factor alpha (TGF $\mathbf{\alpha})$ (Paria and Dey, 1990; Dardik et al., 1993), and WNT3A (Krivega et al., 2015). Further studies on the effects of the proteins encoded by each of the 93 genes expressed in the oviduct and endometrium can be useful to identify additional cell-signaling molecules that act as embryokines.

Many of the cell signaling molecules encoded by the transcripts under investigation may function to regulate physiology of the reproductive tract itself. The angiogenic factor VEGFA was among the 20 most highly expressed genes in the oviduct and among the 10 most highly expressed genes in the endometrium at each day of the estrous cycle. Differential expression of genes involved in angiogenesis have been related to capacity of heifers to become pregnant after embryo transfer (Ponsuksili et al., 2014). In addition, various chemokine genes were highly expressed in both oviduct (including CXCL3, CXCL10, CXCL12, CCL14, and GRO1) and endometrium ( $C X C L 3$ and $C X C L 10$ ). Chemokines participate in limiting bacterial infection in the reproductive tract (Sheldon, 2014). Another highly expressed gene in the endometrium, WNT7A, is involved in uterine gland morphogenesis (Dunlap et al., 2011).

Accumulation of transcripts does not necessarily mean that the protein is synthesized and placed in a location where it can act on the embryo. This is particularly a concern for genes expressed in the oviduct because tissue sections analyzed included all layers of the oviduct. Nonetheless, it is likely that accumulation of mRNA is indicative of protein synthesis in many cases. Indeed, all the proteins examined immunohistochemically (CSF2, DKK1, WNT5A, and WNT7A) were present in the endometrium. Moreover, CSF2 was secreted into the uterine lumen as indicated by the presence of immunoreactive protein in uterine flushings.

The main form of CSF2 detected in uterine flushes was of larger molecular weight $(24,600)$ than the 2 immunoreactive bands in recombinant bovine CSF2 $(22,700$ and 19,600). Although the recombinant CSF2 used was produced in yeast and is subject to posttranslational modifications, it is likely that native CSF2 is more glycosylated than the recombinant protein. Multiple forms of CSF2 have previously been reported in bovine uterine fluid, with bands of 26,000, 28,000, and 40,000 (de Moraes et al., 1999). Similarly, 9 species of immunoreactive CSF2 were isolated from human lymphocytes with differences in size being due to differential glycosylation (Cebon et al., 1990). In that latter study, glycosylation was associated with reduced biological activity.

There was a great deal of variation in transcript abundance among genes. It would be overly simplistic, 


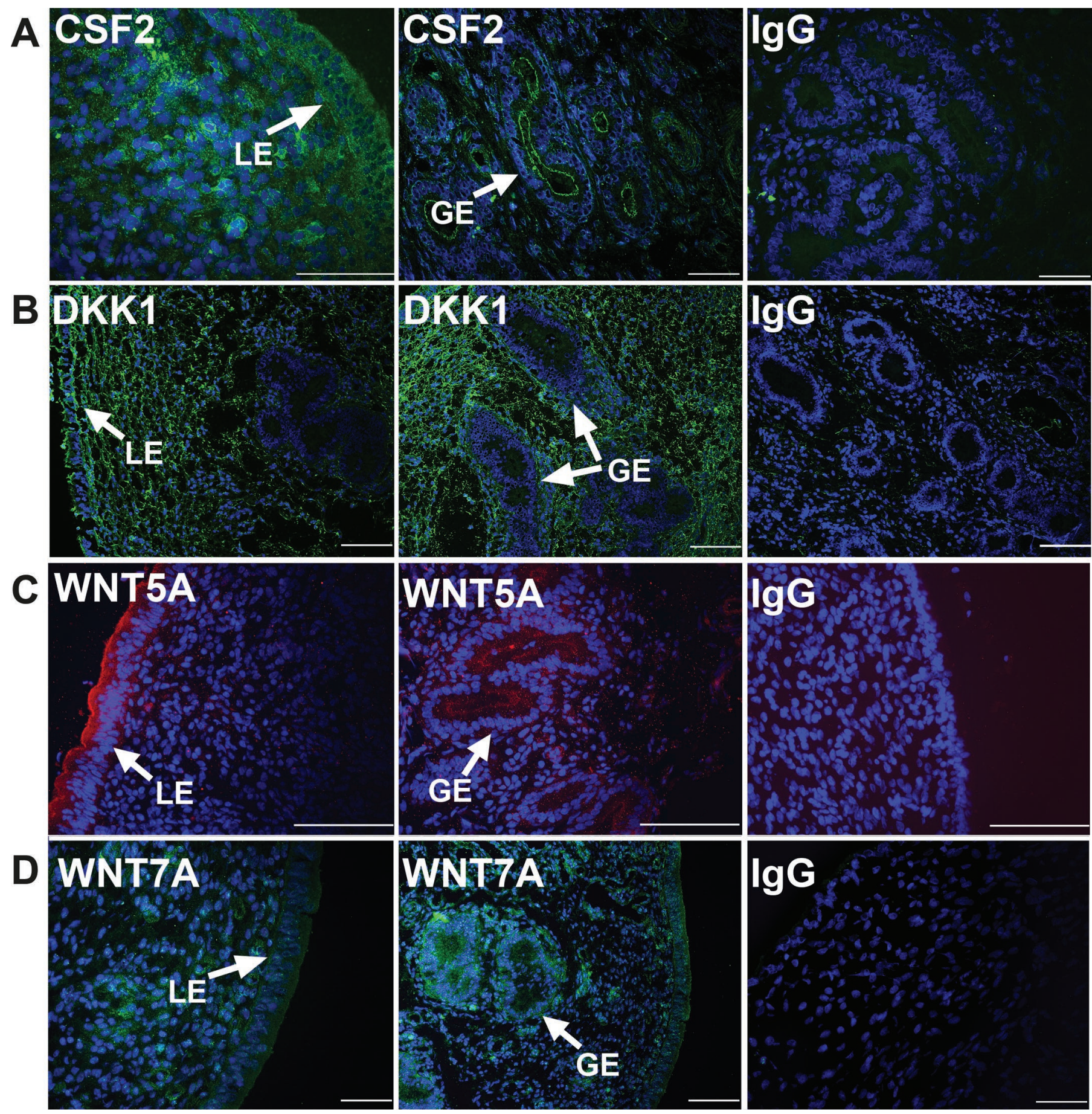

Figure 3. Representative images for immunolocalization of CSF2, DKK1, WNT5A, and WNT7A in endometrium. The DNA was labeled with Hoescht 33342 (gray/blue). (A) CSF2 (gray/green) localized to luminal epithelium (LE), glandular epithelium (GE), and stroma at d 5. (B) DKK1 (gray/green) localized primarily to stroma and with some labeling in the LE. (C) WNT5A (gray/red) localized to LE, GE, and stroma at d 5. (D) WNT7A (gray/green) localized to LE, GE, and stroma at d 7. Note that the magnification varies between panels. Scale bars represent $100 \mu \mathrm{m}$. Color version available online.

however, to assume that genes that are most highly expressed are more important for embryonic development. For cell-signaling molecules, active concentra- tions required for receptor binding are usually low, in the nanomolar range (see, for example, KannampuzhaFrancis et al., 2016). Endometrial expression of 2 well- 


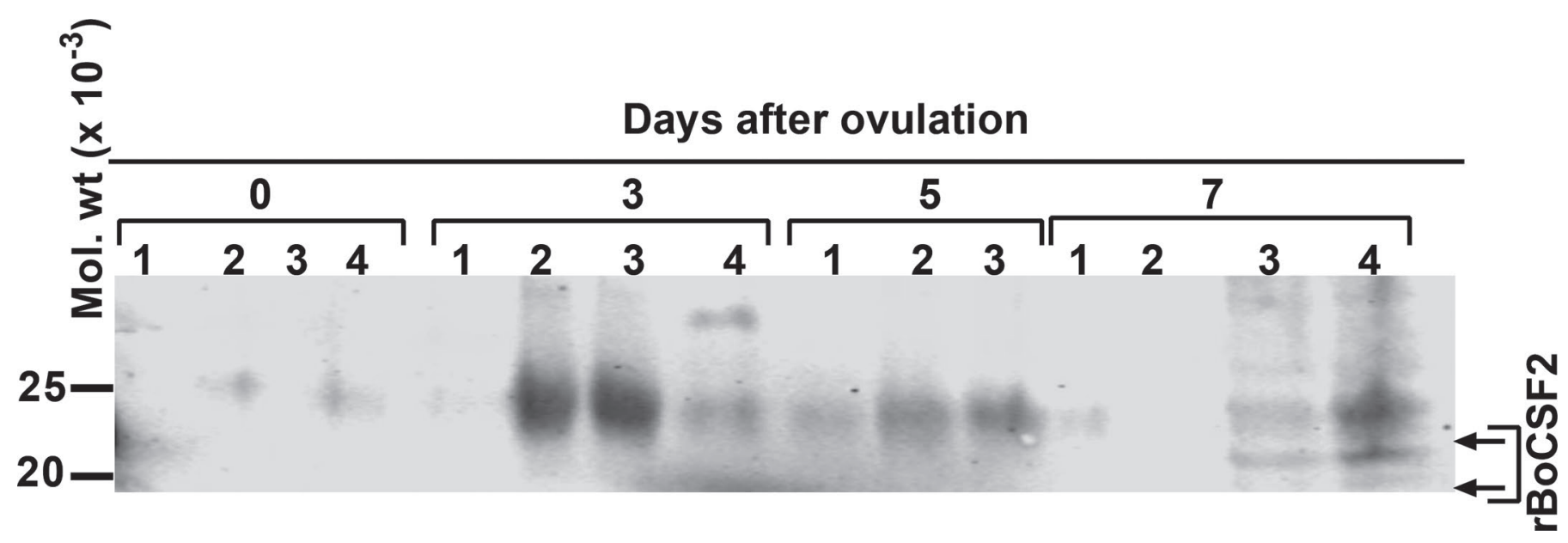

Figure 4. Detection of CSF2 in uterine fluid by Western blotting. Each lane represents a sample of uterine flushings from individual cows at d $0(\mathrm{n}=4), 3(\mathrm{n}=4), 5(\mathrm{n}=3)$, and $7(\mathrm{n}=4)$ after ovulation. The location of molecular weight (Mol. wt) standards at 25 and $20 \mathrm{kDa}$ is shown to the left of the blot, whereas the migration distances of immunoreactive bands of recombinant bovine (rBo) CSF2 are shown by the arrows to the right of the blot.

characterized embryokines, CSF2 and DKK1, was low compared with many other genes. Nonetheless, transcript abundance was sufficient to allow production of detectable amounts of immunoreactive protein in the endometrium.

Examination of cyclic changes in gene expression in both oviduct and endometrium is consistent for a role of ovarian steroids in regulation of some of the genes examined. In oviduct, all 93 genes were expressed at d 0 and d 3 of the estrous cycle, but only 71 were expressed by d 5 and 61 by d 7 . Of the genes significantly affected by day of the estrous cycle, 11 were most highly expressed at d 0, when concentrations of estradiol were high and those of progesterone low; only one was most highly expressed at d 7. For the endometrium, some genes were upregulated at d 0 , whereas another set was upregulated at $d 7$, when estradiol concentrations would be low and progesterone concentrations elevated. While all genes were expressed at $\mathrm{d} 0,3$, and 7 of the estrous cycle, only 69 of the 93 genes were expressed on $\mathrm{d} 5$. Of genes significantly affected by day of the estrous cycle, 12 were most highly expressed at d 0 and another 21 at either d 5 or 7 . In other studies on changes in oviductal and endometrial gene expression during the estrous cycle of the cow, a fraction of genes were differentially expressed between estrus and diestrus (Bauersachs et al., 2004, 2005; Mitko et al., 2008). Steroids play a key role on the regulation of the reproductive tract. Exogenous supplementation of estradiol and progesterone during early stages of the estrous cycle alters the transcriptome of oviduct and endometrium (Groothuis et al., 2007; Forde et al., 2010). Additionally, there are differences in gene expression in the oviduct (Gonella-Diaza et al., 2015, 2017) and endometrium (Mesquita et al., 2015) between cows having a large preovulatory follicle and large corpus luteum and cows having a small preovulatory follicle and small corpus luteum.

Earlier studies indicated that side of the reproductive tract relative to ovulation had an effect on secretion of proteins by oviduct and endometrium (Malayer et al., 1988; Williams et al., 1992) and on expression of specific genes in the endometrium including genes for the progesterone and oxytocin receptors (Araújo et al., 2014). Such a result is consistent with local regulation of the reproductive tract by the preovulatory follicle or incipient corpus luteum. In contrast, expression of few of the genes in the present experiment were affected by side of the reproductive tract. Only 14 genes were differentially expressed between oviducts ipsilateral and contralateral to ovulation, with the majority being upregulated in the ipsilateral oviduct. Moreover, expression of only 7 genes in the endometrium differed between uterine horns at 1 or more days of the estrous cycle. Consistent with our findings was the general lack of effect of side of the reproductive tract on the endometrial transcriptome (Bauersachs et al., 2005). Differences in systemic concentrations of progesterone and accumulation of hexoses and proteins in the uterus between left and right sides of the reproductive tract have been reported (Trigal et al., 2014), and it is possible that some differences between ipsilateral and contralateral sides of the reproductive tract were obscured by differences between the left and right sides of the reproductive tract as well as by the limited number of cows per group. 
Endometrial tissue was collected from the middle of the uterus relative to the oviduct and vagina. This is below the upper third of the endometrium where the embryo is located at d 7 of pregnancy (Sponchiado et al., 2017). There is regional variation in endometrial gene expression, with transcript abundance for many genes varying between the anterior, middle, and posterior third of the uterus (Araújo et al., 2014; Sponchiado et al., 2017). It may be, therefore, that some of the differences in transcript abundance reported in the current paper may not be identical at other regions of the endometrium. The effects of follicle and corpus luteum size on endometrial gene expression were similar for all regions of endometrium examined, however (Araújo et al., 2014).

Taken together, results indicate that the oviduct and endometrium express a wide range of cell-signaling genes that have the potential to participate in regulation of development of the preimplantation embryo. Expression of many of these genes varies with stage of the estrous cycle, suggesting importance of both estradiol and progesterone in regulation of gene expression.

\section{ACKNOWLEDGMENTS}

The authors thank owners and employees of Central Beef Packing Co. (Center Hill, FL) for facilitating reproductive tract collection; staff from the Sumter County Extension Office of University of Florida for providing access to their facility for sample collection; all members of the Hansen laboratory for helping collect tissue samples; and NanoString Biotechnologies (Seattle, WA) for performing the gene expression analyses. This work was supported by the USDA National Institute of Food and Agriculture (Competitive Grant no. 201167015-30688) and the L.E. "Red" Larson Endowment.

\section{REFERENCES}

Araújo, E. R., M. Sponchiado, G. Pugliesi, V. Van Hoeck, F. S. Mesquita, C. M. Membrive, and M. Binelli. 2014. Spatio-specific regulation of endocrine-responsive gene transcription by periovulatory endocrine profiles in the bovine reproductive tract. Reprod. Fertil. Dev. 28:1533-1544.

Bauersachs, S., S. Rehfeld, S. E. Ulbrich, S. Mallok, K. Prelle, H. Wenigerkind, R. Einspanier, H. Blum, and E. Wolf. 2004. Monitoring gene expression changes in bovine oviduct epithelial cells during the oestrous cycle. J. Mol. Endocrinol. 32:449-466.

Bauersachs, S., S. E. Ulbrich, K. Gross, S. E. M. Schmidt, H. H. D. Meyer, R. Einspanier, H. Wenigerkind, M. Vermehren, H. Blum, F. Sinowatz, and E. Wolf. 2005. Gene expression profiling of bovine endometrium during the oestrous cycle: Detection of molecular pathways involved in functional changes. J. Mol. Endocrinol. 34:889-908.

Betteridge, K., and J. Fléchon. 1988. The anatomy and physiology of the pre-attachment bovine embryos. Theriogenology 29:155-187.

Boni, R., E. Tosti, S. Roviello, and B. Dale. 1999. Intercellular communication in in vivo- and in vitro-produced bovine embryos. Biol. Reprod. 61:1050-1055.
Bonilla, A. Q. S., M. Ozawa, and P. J. Hansen. 2011. Timing and dependence upon mitogen-activated protein kinase signaling for prodevelopmental actions of insulin-like growth factor 1 on the preimplantation bovine embryo. Growth Horm. IGF Res. 21:107-111.

Cebon, J., N. Nicola, M. Ward, I. Gardner, P. Dempsey, J. Layton, U. Duhrsen, A. W. Burgess, E. Nice, and G. Morstyn. 1990. Granulocyte-macrophage colony stimulating factor from human lymphocytes The effect of glycosylation on receptor binding and biological activity. J. Biol. Chem. 265:4483-4491.

Ceelen, M., M. M. van Weissenbruch, J. P. W. Vermeiden, F. E. van Leeuwen, and H. A. Delemarre-van De Waal. 2008. Cardiometabolic differences in children born after in vitro fertilization: Followup study. J. Clin. Endocrinol. Metab. 93:1682-1688.

Corcoran, D., T. Fair, S. Park, D. Rizos, O. V. Patel, G. W. Smith, P. M. Coussens, J. J. Ireland, M. P. Boland, A. C. O. Evans, and P. Lonergan. 2006. Suppressed expression of genes involved in transcription and translation in in vitro compared with in vivo cultured bovine embryos. Reproduction 131:651-660.

Crosier, A. E., P. W. Farin, M. J. Dykstra, J. E. Alexander, and C. E. Farin. 2000. Ultrastructural morphometry of bovine compact morulae produced in vivo or in vitro. Biol. Reprod. 62:1459-1465.

Dardik, A., A. S. Doherty, and R. M. Schultz. 1993. Protein secretion by the mouse blastocyst-stimulatory effect on secretion into the blastocoele by transforming growth factor- $\alpha$. Mol. Reprod. Dev. 34:396-401.

de Moraes, A. A. S., F. F. Paula-Lopes, N. Chegini, and P. J. Hansen. 1999. Localization of granulocyte-macrophage colony-stimulating factor in the bovine reproductive tract. J. Reprod. Immunol. 42:135-145.

Denicol, A. C., J. Block, D. E. Kelley, K. G. Pohler, K. B. Dobbs, C. J. Mortensen, M. S. Ortega, and P. J. Hansen. 2014. The WNT signaling antagonist Dickkopf-1 directs lineage commitment and promotes survival of the preimplantation embryo. FASEB J. $28: 3975-3986$

Dunlap, K., J. Filant, K. Hayashi, E. B. Rucker, G. Song, J. M. Deng, R. R. Behringer, F. J. De Mayo, J. Lydon, J. W. Jeong, and T. E. Spencer. 2011. Postnatal deletion of Wnt7a inhibits uterine gland morphogenesis and compromises adult fertility in mice. Biol. Reprod. 85:386-396.

Enright, B. P., P. Lonergan, T. Fair, F. A. Ward, X. Yang, and M. P. Boland. 2000. Culture of in vitro produced bovine zygotes in vitro vs in vivo: Implications for early embryo development and quality. Theriogenology 54:659-673.

Farin, P. W., J. A. Piedrahita, and C. E. Farin. 2006. Errors in development of fetuses and placentas from in vitro-produced bovine embryos. Theriogenology 65:178-191.

Fernandez-Gonzalez, R., P. Moreira, A. Bilbao, A. Jimenez, M. Perezcrespo, M. A. Ramírez, F. Rodríguez De Fonseca, B. Pintado, A. Guitierrez-Adan, and A. Gutie. 2004. Long-term effect of in vitro culture of mouse embryos with serum on mRNA expression of imprinting genes, development, and behavior. Proc. Natl. Acad. Sci. USA 101:5880-5885.

Fields, S. D., P. J. Hansen, and A. D. Ealy. 2011. Fibroblast growth factor requirements for in vitro development of bovine embryos. Theriogenology 75:1466-1475.

Fleming, T. P., A. J. Watkins, C. Sun, M. A. Velazquez, R. Neil, and J. J. Eckert. 2015. Do little embryos make big decisions? How maternal dietary protein restriction can permanently change an embryo's potential, affecting adult health. Reprod. Fertil. Dev. 27:684-692.

Forde, N., F. Carter, T. Fair, M. A. Crowe, A. C. O. Evans, T. E. Spencer, F. W. Bazer, R. McBride, M. P. Boland, P. O'Gaora, P. Lonergan, and J. F. Roche. 2009. Progesterone-regulated changes in endometrial gene expression contribute to advanced conceptus development in cattle. Biol. Reprod. 81:784-794.

Forde, N., T. E. Spencer, F. W. Bazer, G. Song, J. F. Roche, and P. Lonergan. 2010. Effect of pregnancy and progesterone concentration on expression of genes encoding for transporters or secreted proteins in the bovine endometrium. Physiol. Genomics 41:53-62.

Gad, A., M. Hoelker, U. Besenfelder, V. Havlicek, U. Cinar, F. Rings, E. Held, I. Dufort, M.-A. Sirard, K. Schellander, and D. Tesfaye. 
2012. Molecular mechanisms and pathways involved in bovine embryonic genome activation and their regulation by alternative in vivo and in vitro culture conditions. Biol. Reprod. 87:100.

Geiss, G. K., R. E. Bumgarner, B. Birditt, T. Dahl, N. Dowidar, D. L. Dunaway, H. P. Fell, S. Ferree, R. D. George, T. Grogan, J. J. James, M. Maysuria, J. D. Mitton, P. Oliveri, J. L. Osborn, T. Peng, A. L. Ratcliffe, P. J. Webster, E. H. Davidson, L. Hood, and K. Dimitrov. 2008. Direct multiplexed measurement of gene expression with color-coded probe pairs. Nat. Biotechnol. 26:317325 .

Gómez, E., E. Correia-Álvarez, J. N. Caamaño, C. Díez, S. Carrocera, N. Peynot, D. Martín, C. Giraud-Delville, V. Duranthon, O. Sandra, and M. Muñoz. 2014. Hepatoma-derived growth factor: From the bovine uterus to the in vitro embryo culture. Reproduction 148:353-365.

Gonella-Diaza, A. M., S. C. da Silva Andrade, M. Sponchiado, G. Pugliesi, F. S. Mesquita, V. Van Hoeck, R. de Francisco Strefezzi, G. R. Gasparin, L. L. Coutinho, and M. Binelli. 2015. Size of the ovulatory follicle dictates spatial differences in the oviductal transcriptome in cattle. PLoS One 10:e0145321.

Gonella-Diaza, A. M., S. C. da Silva Andrade, M. Sponchiado, G. Pugliesi, F. S. Mesquita, V. Van Hoeck, R. de Francisco Strefezzi, G. R. Gasparin, L. L. Coutinho, and M. Binelli. 2017. Oviductal transcriptional profiling of a bovine fertility model by next-generation sequencing. Genom. Data 13:27-29.

Graf, A., S. Krebs, V. Zakhartchenko, B. Schwalb, H. Blum, and E. Wolf. 2014. Fine mapping of genome activation in bovine embryos by RNA sequencing. Proc. Natl. Acad. Sci. USA 111:4139-4144.

Groothuis, P. G., H. H. N. M. Dassen, A. Romano, and C. Punyadeera. 2007. Estrogen and the endometrium: Lessons learned from gene expression profiling in rodents and human. Hum. Reprod. Update 13:405-417.

Hansen, P. J., K. B. Dobbs, A. C. Denicol, and L. G. B. Siqueira. 2016. Sex and the preimplantation embryo: Implications of sexual dimorphism in the preimplantation period for maternal programming of embryonic development. Cell Tissue Res. 363:237-247.

Jousan, F. D., and P. J. Hansen. 2007. Insulin-like growth factor-I promotes resistance of bovine preimplantation embryos to heat shock through actions independent of its anti-apoptotic actions requiring PI3K signaling. Mol. Reprod. Dev. 74:189-196.

Kannampuzha-Francis, J., P. Tribulo, and P. J. Hansen. 2016. Actions of activin A, connective tissue growth factor, hepatocyte growth factor and teratocarcinoma-derived growth factor 1 on the development of the bovine preimplantation embryo. Reprod. Fertil. Dev. 29:1329-1339.

Kauma, S. W., and D. W. Matt. 1995. Coculture cells that express leukemia inhibitory factor (LIF) enhance mouse blastocyst development in vitro. J. Assist. Reprod. Genet. 12:153-156.

Khurana, N. K., and H. Niemann. 2000. Energy metabolism in preimplantation bovine embryos derived in vitro or in vivo. Biol. Reprod. 62:847-856.

Krivega, M., W. Essahib, and H. Van de Velde. 2015. WNT3 and membrane-associated $\beta$-catenin regulate trophectoderm lineage differentiation in human blastocysts. Mol. Hum. Reprod. 21:711722 .

La Rosa, I., L. S. A. Camargo, M. M. Pereira, R. Fernandez-Martin, D. A. Paz, and D. F. Salamone. 2011. Effects of bone morphogenic protein 4 (BMP4) and its inhibitor, Noggin, on in vitro maturation and culture of bovine preimplantation embryos. Reprod. Biol. Endocrinol. 9:18.

Lazzari, G., S. Colleoni, I. Lagutina, G. Crotti, and P. Turini. 2010. Short-term and long-term effects of embryo culture in the surrogate sheep oviduct versus in vitro culture for different domestic species. Theriogenology 73:748-757.

Lin, T. C., J.-M. Yen, K.-B. Gong, T.-T. Hsu, and L.-R. Chen. 2003. IGF-I/IGFBP-I increases blastocyst formation and total cell number in mouse embryo culture and facilitates the establishment of a stem-cell line. BMC Cell Biol. 4:14.

Lonergan, P., A. Woods, T. Fair, F. Carter, D. Rizos, F. Ward, K. Quinn, and A. Evans. 2007. Effect of embryo source and recipi- ent progesterone environment on embryo development in cattle. Reprod. Fertil. Dev. 19:861-868.

Loureiro, B., L. Bonilla, J. Block, J. Fear, A. Bonilla, and P. J. Hansen. 2009. Colony-stimulating factor 2 (CSF-2) improves development and posttransfer survival of bovine embryos produced in vitro. Endocrinology 150:5046-5054.

Loureiro, B., L. J. Oliveira, M. G. Favoreto, and P. J. Hansen. 2011. Colony-stimulating factor 2 inhibits induction of apoptosis in the bovine preimplantation embryo. Am. J. Reprod. Immunol. 65:578588

Malayer, J. R., P. J. Hansen, and W. C. Buhi. 1988. Effect of day of the oestrous cycle, side of the reproductive tract and heat shock on in vitro protein secretion by bovine endometrium. J. Reprod. Fertil. 84:567-578.

McHughes, C. E., G. K. Springer, L. D. Spate, R. Li, R. Woods, M. P. Green, S. W. Korte, C. N. Murphy, J. A. Green, and R. S. Prather. 2009. Identification and quantification of differentially represented transcripts in in vitro and in vivo derived preimplantation bovine embryos. Mol. Reprod. Dev. 76:48-60.

Menino, A. R., J. S. Williams, C. S. Gardiner, and T. L. John. 1989. Mouse embryo development in media containing growth factors. Anim. Reprod. Sci. 18:125-137.

Mesquita, F. S., R. S. Ramos, G. Pugliesi, S. C. S. Andrade, V. Van Hoeck, A. Langbeen, M. L. Oliveira, A. M. Gonella-Diaza, G. Gasparin, H. Fukumasu, and L. H. Pulz. 2015. The receptive endometrial transcriptomic signature indicates an earlier shift from proliferation to metabolism at early diestrus in the cow. Biol. Reprod. 93:52.

Mitko, K., S. E. Ulbrich, H. Wenigerkind, F. Sinowatz, H. Blum, E. Wolf, and S. Bauersachs. 2008. Dynamic changes in messenger RNA profiles of bovine endometrium during the oestrous cycle. Reproduction 135:225-240.

Mo, X., G. Wu, D. Yuan, B. Jia, C. Liu, S. Zhu, and Y. Hou. 2014. Leukemia inhibitory factor enhances bovine oocyte maturation and early embryo development. Mol. Reprod. Dev. 81:608-618.

Mohamed, O. A., D. Dufort, H. J. Clarke, D. Obstetrics, C. H. J. Clarke, D. Dufort, F. Room, V. Hospital, P. A. West, and Q. C. C. Ha. 2004. Expression and estradiol regulation of Wnt genes in the mouse blastocyst identify a candidate pathway for embryomaternal signaling at implantation. Biol. Reprod. 71:417-424.

Moreira, F., L. Badinga, C. Burnley, and W. W. Thatcher. 2002. Bovine somatotropin increases embryonic development in superovulated cows and improves post-transfer pregnancy rates when given to lactating recipient cows. Theriogenology 57:1371-1387.

Neira, J. A., D. Tainturier, M. A. Peña, and J. Martal. 2010. Effect of the association of IGF-I, IGF-II, bFGF, TGF $\beta 1$, GM-CSF, and LIF on the development of bovine embryos produced in vitro. Theriogenology 73:595-604.

Niemann, H., J. W. Carnwath, D. Herrmann, G. Wieczorek, E. Lemme, A. Lucas-Hahn, and S. Olek. 2010. DNA methylation patterns reflect epigenetic reprogramming in bovine embryos. Cell. Reprogram. 12:33-42.

Paria, B. C., and S. K. Dey. 1990. Preimplantation embryo development in vitro: Cooperative interactions among embryos and role of growth factors. Proc. Natl. Acad. Sci. USA 87:4756-4760.

Paula-Lopes, F. F., A. A. de Moraes, J. L. Edwards, J. E. Justice, and P. J. Hansen. 1998. Regulation of preimplantation development of bovine embryos by interleukin-1 $\beta$. Biol. Reprod. 59:1406-1412.

Ponsuksili, S., D. Tesfaye, K. Schellander, M. Hoelker, F. Hadlich, M. Schwerin, and K. Wimmers. 2014. Differential expression of miRNAs and their target mRNAs in endometria prior to maternal recognition of pregnancy associates with endometrial receptivity for in vivo- and in vitro-produced bovine embryos. Biol. Reprod. 91:135.

Pontes, J. H. F., I. Nonato-Junior, B. V. Sanches, J. C. Ereno-Junior, S. Uvo, T. R. R. Barreiros, J. A. Oliveira, J. F. Hasler, and M. M. Seneda. 2009. Comparison of embryo yield and pregnancy rate between in vivo and in vitro methods in the same Nelore (Bos indicus) donor cows. Theriogenology 71:690-697. 
Rizos, D., F. Ward, P. A. T. Duffy, M. P. Boland, and P. Lonergan. 2002. Consequences of bovine oocyte maturation, fertilization or early embryo development in vitro versus in vivo: Implications for blastocyst yield and blastocyst quality. Mol. Reprod. Dev. $61: 234-248$.

Sakagami, N., H. Umeki, O. Nishino, H. Uchiyama, K. Ichikawa, K. Takeshita, E. Kaneko, and K. Akiyama. 2012. Normal calves produced after transfer of embryos cultured in a chemically defined medium supplemented with epidermal growth factor and insulinlike growth factor I following ovum pick up and in vitro fertilization in Japanese back cows. J. Reprod. Dev. 58:140-146.

Sheldon, I. M. 2014. Genes and environmental factors that influence disease resistance to microbes in the female reproductive tract of dairy cattle. Reprod. Fertil. Dev. 27:72-81.

Simón, C., F. Cano, D. Valbuena, J. Remohi, and A. Pellicer. 1995. Clinical evidence of detrimental effect on uterine receptivity of high serum oestradiol concentrations in high and normal responder patients. Hum. Reprod. 10:2432-2437.

Siqueira, L. G. B., S. Dikmen, M. S. Ortega, and P. J. Hansen. 2017. Postnatal phenotype of dairy cows is altered by in vitro embryo production using reverse X-sorted semen. J. Dairy Sci. 100:58995908.

Sjoblom, C., M. Wikland, and S. A. Robertson. 1999. Granulocytemacrophage colony-stimulating factor promotes human blastocyst development in vitro. Hum. Reprod. 14:3069-3076.

Sponchiado, M., N. S. Gomes, P. K. Fontes, T. Martins, M. del Collado, A. de Assumpção Pastore, G. Pugliesi, M. F. G. Nogueira, and M. Binelli. 2017. Pre-hatching embryo-dependent and-independent programming of endometrial function in cattle. PLoS One 12:e0175954.

Sudano, M. J., V. G. Santos, A. Tata, C. R. Ferreira, D. M. Paschoal, M. N. Eberlin, F. D. Landim-Alvarenga, and R. Machado. 2012.
Phosphatidylcholine and sphingomyelin profiles vary in Bos taurus indicus and Bos taurus taurus in vitro- and in vivo-produced blastocysts. Biol. Reprod. 87:130.

Tribulo, P., B. Caetano da Silva Leão, K. C. Lehloenya, G. S. Mingoti, and P. J. Hansen. 2017. Consequences of endogenous and exogenous WNT signaling for development of the preimplantation bovine embryo. Biol. Reprod. 96:1129-1141.

Trigal, B., C. Díez, M. Muñoz, J. N. Caamaño, F. Goyache, E. Correia-Alvarez, F. J. Corrales, M. I. Mora, S. Carrocera, D. Martin, and E. Gómez. 2014. Elements of functional genital asymmetry in the cow. Reprod. Fertil. Dev. 26:493-501.

Trigal, B., E. Gómez, C. Díez, J. N. Caamaño, D. Martín, S. Carrocera, and M. Muñoz. 2011. In vitro development of bovine embryos cultured with activin A. Theriogenology 75:584-588.

Williams, B. L., F. C. Gwazdauskas, and R. E. Pearson. 1992. The effect of day of the estrous cycle, location of ovulatory structure, and progesterone on in vitro bovine endometrial secretions. J. Dairy Sci. 75:2112-2118.

Xiao, S., H. Diao, M. A. Smith, X. Song, and X. Ye. 2011. Preimplantation exposure to bisphenol A (BPA) affects embryo transport, preimplantation embryo development, and uterine receptivity in mice. Reprod. Toxicol. 32:434-441.

Yoshinaga, K., and C. E. Adams. 1966. Delayed implantation in the spayed, progesterone treated adult mouse. J. Reprod. Fertil. 12:593-595.

Zuo, Y., G. Su, S. Wang, L. Yang, M. Liao, Z. Wei, C. Bai, and G. Li. 2016. Exploring timing activation of functional pathway based on differential co-expression analysis in preimplantation embryogenesis. Oncotarget 7:74120-74131. 